\title{
A Critical Analysis of the Belt and Road Initiative in Central Asia
}

\author{
Diana Toktogulova ${ }^{1}$, Weiqing Zhuang ${ }^{2 *}$ \\ ${ }^{1}$ School of Management, Fujian University of Technology, Fuzhou, Fujian, China 350118 \\ ${ }^{2}$ School of Internet Economics and Business, Fujian University of Technology, Fuzhou 350108, \\ China \&Research Center for "One Belt and One Road" Economic and Policy, Fujian University of Technology, \\ Fuzhou 350108, China
}

\begin{abstract}
*Corresponding Author:WeiqingZhuang, School of Internet Economics and Business, Fujian University of Technology, Fuzhou 350108, China \& Research Center for "One Belt and One Road" Economic and Policy, Fujian University of Technology, Fuzhou 350108, China
\end{abstract}

\begin{abstract}
The Belt and Road initiative seeks to bring Asia and countries in the Middle East, Europe and Africa on a new road of higher growth and human development through integration with infrastructure, increased trade and investment. This paper aims at analyzing the economic impact of BRI in Central Asia by assessing investment and trade between China and participating countries in Central Asia after the introduction of BRI in 2013. Extensive review of relevant literature and data from research publications and institutions involved in BRI were critically analyzed to effectively assess the impact of BRI in Central Asia. It was observed that the annual turnover of trade between China declined from 2013-2016 and started to gradually increase since 2016. Projects within each country in the region were summarized and categorized into the industry, road and railway, energy, mineral, petroleum extraction, finance and IT, agriculture, workshop, and training. Among these categories China has invested heavily in projects under the category mineral and petroleum extraction. The key challenge China faces with the implementation of BRI within the region is from locals who feel China benefits from the initiative more than the participating countries within the region.
\end{abstract}

Keywords:Belt and Road Initiative (BRI), China, Central Asia, trade.

\section{INTRODUCTION}

\subsection{Background}

In about 4 decades after the beginning of the economic reforms, China has risen to become a major economic power moving over 800 million from poverty and growing at an annual average growth of 10percent making them the world most fastest sustained expansion grow by a major economy in history between 1976-2017 according to World Bank [1]. After such great economic growth, China has been trying to strengthen its connectivity with the world in recent years. So, in order to further strengthen it, President Xi Jinping in 2013, outlines his vision to revive China's cultural and commercial links with Eurasia that was a feature of the ancient Silk Road which he called the Belt and Road Initiative [2]. This initiative will further strengthen its connectivity with the world [3]. The idea of this initiative comes from a network of trade routes name "Silk Road" that was established 2,000 years ago by China's Emperor Zhang Qian linking China to Central Asia and the Arabian countries. The most important things exported during that time were silk and this contributed to the development of the entire region of hundreds of years [4].

\subsection{Belt and Road Initiative}

The reintroduction of this idea which is geared towards strengthening China's connectivity to the world by encouraging exchanges and the spirit of regional cooperation between Asia, Europe, and Africa by creating jointly built trade routes emulating the ancient Silk Road [5]. It will also strengthen economic flow, create job opportunities, investment, consumption and culture [6].

The BRI is also known as "one belt one road" with "one belt" refereeing to the silk road economic belt envision to connect by land between China, Europe (via Central Asia), the Persian Gulf, The 
Mediterranean (through West Asia) and the Indian Ocean (via South Asia)" and "one road referring the twenty-first-century maritime road envision to create connections among regional waterways [7][4]. The initiative initially involved 64 countries but has been broadened in scope to 100 countries. The participating countries are provided in Table 1.0 below [8], they are group base on the World Bank's classification of the region [9].

Table1.0.Participating countries in BRI -China International Institute, cited in [8][9].

\begin{tabular}{|l|l|}
\hline Region & Country \\
\hline East Asia & People's Republic of China, Mongolia \\
\hline Southeast Asia & $\begin{array}{l}\text { Brunei, Cambodia, Indonesia, Lao People's Democratic Republic, Malaysia, } \\
\text { Myanmar, Philippines, Singapore, Thailand, Timor-Leste, Viet Nam }\end{array}$ \\
\hline Central Asia & Kazakhstan, Kyrgyzstan, Tajikistan, Turkmenistan, Uzbekistan \\
\hline $\begin{array}{l}\text { The Middle East and } \\
\text { North Africa }\end{array}$ & $\begin{array}{l}\text { Bahrain, Egypt, Iran, Iraq, Israel, Jordan, Kuwait, Lebanon, Oman, Qatar, Saudi } \\
\text { Arabia, Palestinian Authority, Syria, United Arab Emirates, Yemen }\end{array}$ \\
\hline South Asia & Afghanistan, Bangladesh, Bhutan, India, Maldives, Nepal, Pakistan, Sri Lanka \\
\hline Europe & $\begin{array}{l}\text { Albania, Armenia, Azerbaijan, Belarus, Bosnia and Herzegovina, Bulgaria, Croatia, } \\
\text { Czech Republic, Estonia, Georgia, Hungary, Latvia, Lithuania, Former Yugoslav } \\
\text { Republic of Macedonia, Moldova, Montenegro, Poland, Romania, Russian } \\
\text { Federation, Serbia, Slovakia, Slovenia, Turkey, Ukraine }\end{array}$ \\
\hline $\begin{array}{l}\text { 21st Century } \\
\text { Maritime Silk Road }\end{array}$ & Ethiopia, Kenya, Morocco, New Zealand, Panama, Korea, South Africa \\
\hline
\end{tabular}

The routes linking most of the participating countries are represented in Figure 1.0 below.

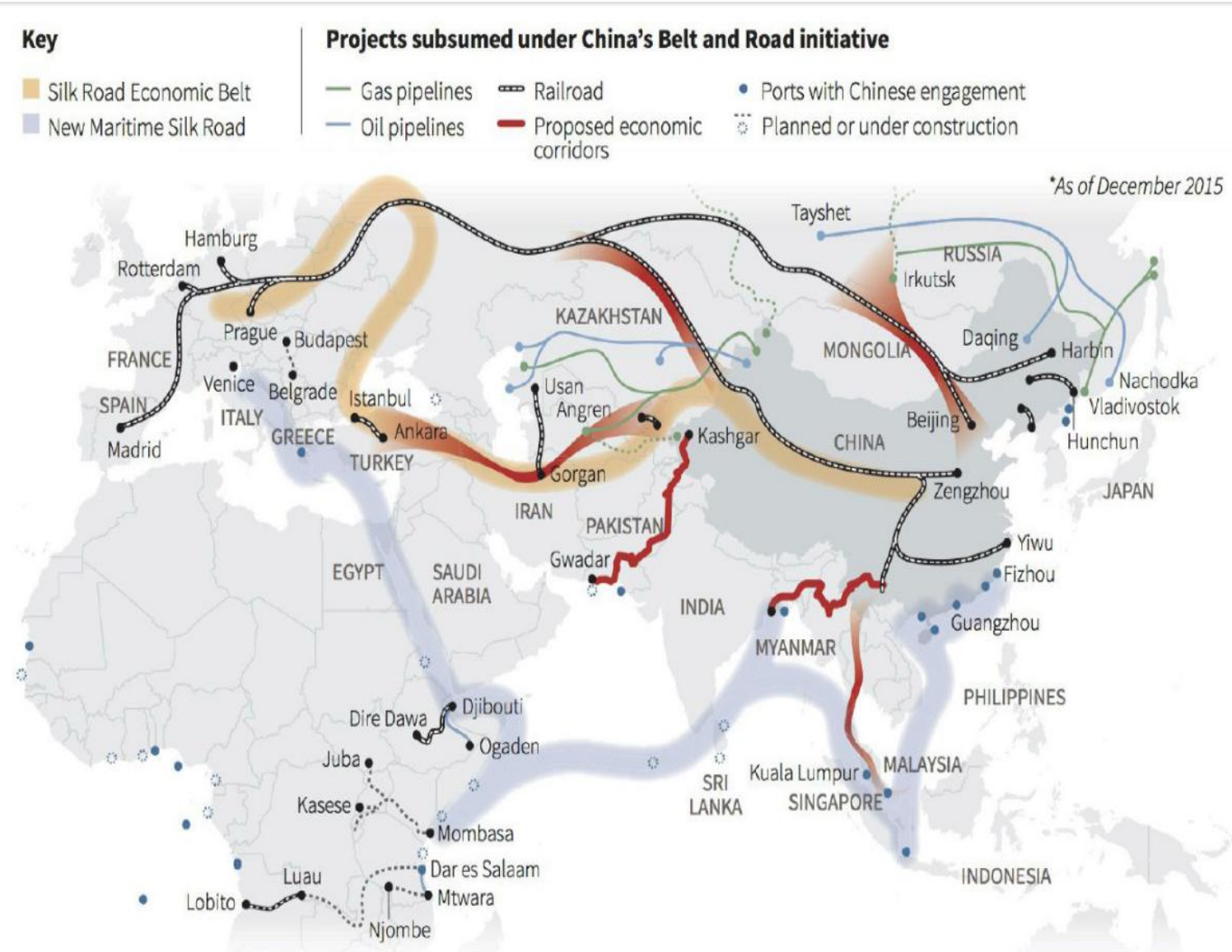

Figure1.Map of BRI regions and products -Mercator Institute for China, cited in [10]

It is estimated the initiative will affect more than 60 percent of the world population contributing to about 35 percent of the global economy and 40 percent of the world trade with a large part being by sea [11]. According to IMF World Economic Outlook, World Bank and World Factbook, the total GDP of participating countries as of January 2020 was USD 28 trillion with East Asia being the highest contributor thus accounting for 49 percent and Central Asia accounting 1 percent which is the 
lowest [12]. Each region's contributing to the total GDP in terms of percentage are represented in Figure 2 below

\section{GDP of Participating Countries}

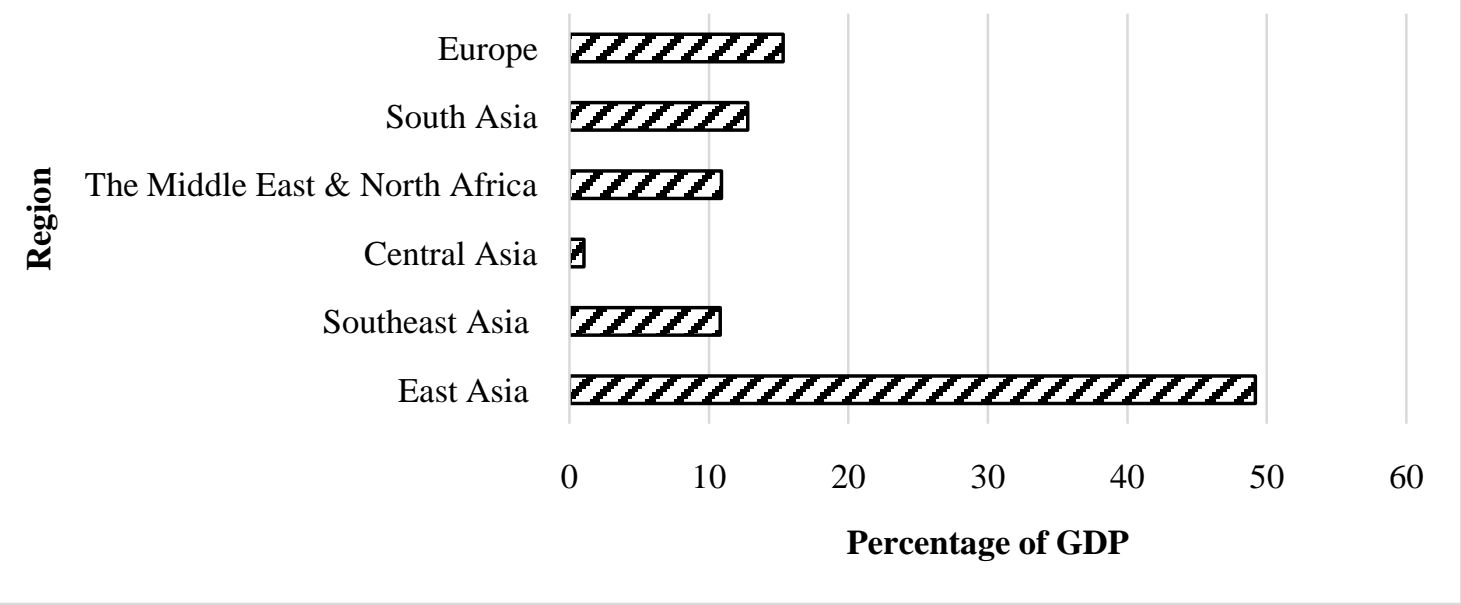

Figure2.GDP of Participating Countries

Since 2013, the total Central Asian countries trade turnover with China in 2013 peaked at $\$ 40.5$ billion, dropped to just over $\$ 19$ billion by 2016 , and reached $\$ 27.2$ billion in 2013 [1] [13]. A graphical representation is presented in Figure 3 below.

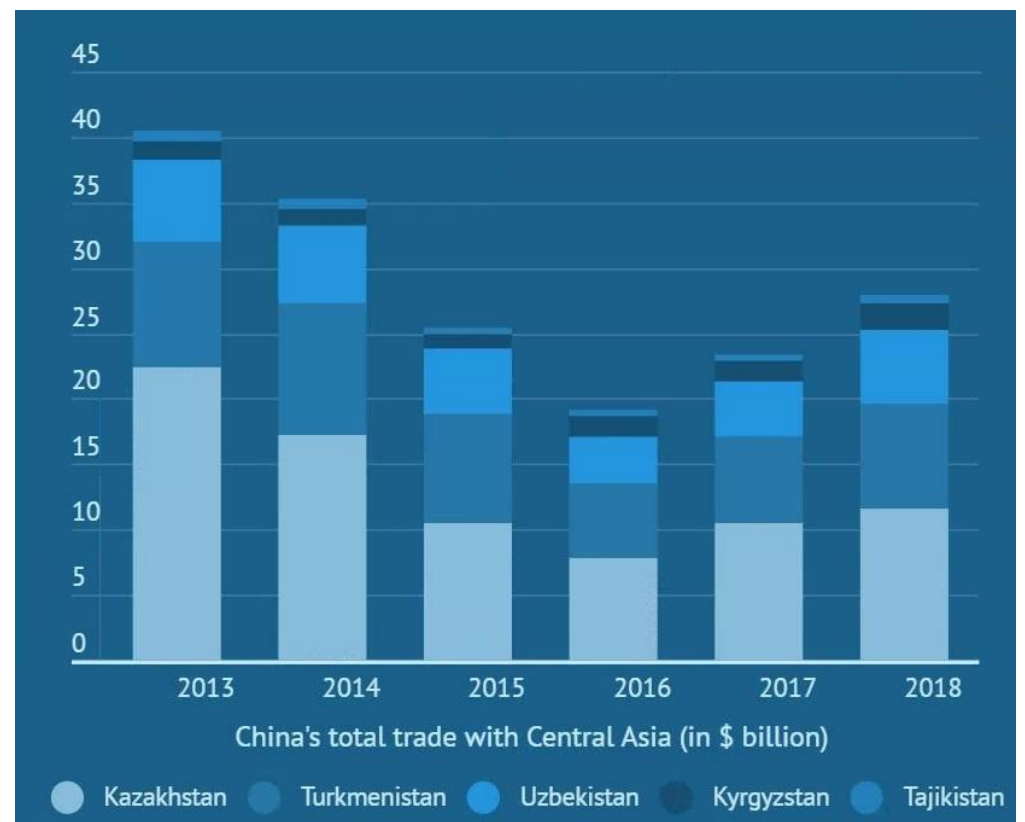

Figure3.Trade between China and BRI participating countries [13]

Between 2013-2018, there has been over US\$614 billion worth of BRI investment and contracts [9]. At the beginning of 2019, the initiative involved 130 countries representing $41 \%$ of world GDP and $49 \%$ of trade [14].

\section{BELT AND RoAd INITIATIVE IN CENTRAL ASIA}

\subsection{China's Presence in the Region}

China in recent years under BRI has contributed to infrastructural development that is within Central Asia to connect Central Asia and Europe. China's presence in the region has been existing prior to the introduction of the BRI. In 2007, the official bilateral trade between Kazakhstan and China in 2007 alone was US\$13.9 billion [24]. Since 2000, 80 percent of Turkmenistan export goes to China which 25, 30, and 40 percent of Tajikistan, Kyrgyzstan and Kazakhstan imports are from China [15]. In 
2007, Turkmenistan extended a license to explore and extract natural gas in the pre-agreed territory of Bagtyyarlyk, located on the right bank of the River Amudarya to the Chinese petroleum and natural gas deposit operator, China National Petroleum Corporation (CNPC).

In Uzbekistan, after the landmark state visit of Chinese leader Hu Jintao to Tashkent in June 2004 which gave impetus to Sino-Uzbek economic relations [16]. Uzbekistan received in agreement and contracts amounting to US\$5.3 billion in 2012. In September 2013, President Xi Jinping's first state visit resulted in projects totaling $\$ 15$ billion and a treaty of amity and cooperation. In addition, Uzbekistan has been persistent in its attempts to reorient China's economic presence in the country toward the development of industrial cooperation in its economic relations with China [17].

The program is expected to involve over US $\$ 1$ trillion in investments, largely in infrastructure development for ports, roads, railways, and airports, as well as power plants and telecommunications networks [18].

\subsection{BRI in Central Asia}

When BRI was launched in 2013, trade between China and the five Central Asian states amounted to US\$50 billion, whilst the region trade with Russia, previously the region's top economic playeramounted to only US\$30 billion [19]. This is clear evidence of the increase in Chinese presence after the introduction of BRI.

In Kyrgyzstan alone, despite the recent increase in customs tariffs on goods imported from China, trade form China to Kyrgyzstan in 2016 amounted to about US\$1.6 billion (exports-US\$80 million; imports-USUS $\$ 1.5$ billion), accounting for a 45 percent increase over 2015 [20]. Also, in 2017, Kyrgyzstan import and export from and to China accounted for 33.4 percent and 5.4 percent of the total import and export respectively [15]. China contributed to 37 percent of the total of US\$814 million foreign direct investment (FDI) received in 2016 making China their biggest contributor.

China's influences in Tajikistan's economy became deeper when Dushanbe agreed to hand over around 1 percent of its territory to Beijing in exchange for having some of its debts forgiven in 2011. In addition, China in 2015 invested US\$273 million in Tajikistan, which was 58 percent of the total foreign direct investment making them their highest direct foreign investor [21].

Out of Kazakhstan their total import and export in 2017, they exported 12 percent of their total export to China and imported 16 percent. In the same year, the trade between China and Turkmenistan exceeded USD 6.9 billion in 2017 [15]. Between 2015-2017 five agreements have been signed between Kazakhstan and China to create cluster cooperation zones in transport infrastructure, trade, processing industries, construction, agriculture, and other areas. In the last five years, China's investments in Kazakhstan have increase about seven-times [22]

\section{ProjeCted Impact on the Region}

\subsection{Kazakhstan}

Kazakhstan links the large and fast-growing markets of China and South Asia and those of Russia and Western Europe by road, rail and a port on the Caspian Sea [23].

Since the introduction of the BRI in 2013, the Kazakh-Chinese border now has a collection of cranes, railways, and buildings rise out of a barren stretch of desert surrounded by towering mountains forming the backbone of the Khorgos Gateway [24]. Because of the countries lack of adequate transportation infrastructure, President Nursultan Nazarbayev of Kazakhstan in 2015, signed a declaration of coordination between BRI and the country's infrastructure development plan to help address the transportation infrastructure gap [25][26]. The contribution to Kazakhstan's economic development in recent years has given China control of up to 30 percent of all oil extraction in Kazakhstan as of April 2016, according to Ardak Kasymbek, managing director for economics and finance at Kazakhstan's state energy company, KazMunayGas [27]. Moreover, the launch of the China-Kazakhstan Railway and China-Kazakhstan International Border Cooperation Center at Khorgos in December 2011 also manifested the tightened business relationship between the two countries [28]. 


\subsection{Kyrgyzstan}

In terms of trade, Kyrgyzstan is the most open economy in the region with 98.5 percent trade openness in terms of both trade and financial flow [15]. Whereas Kazakhstan is a major energy resource partner for China, Kyrgyzstan offers important transit routes and provides the region's wholesale market for affordable Chinese consumer goods. Since Kyrgyzstan has been the only country in Central Asia to share World Trade Organization membership with China for several years, the two countries' low trade protection barriers have allowed Kyrgyzstan to become a major trade and re-export hub to the rest of the region. However, political turmoil and weak economic development make Kyrgyzstan vulnerable to (and overwhelmed by) China's commercial and economic expansion [20].Some of the projects in Kyrgyzstan under BRI include the alternative North-South artery, which leads from Balykchy in the Northeast to Djalal-Abad in the South. The refurbishment of the heat and power station. New high voltage power line to connect the north and south of the country [29].

\subsection{Tajikistan}

One of the factors contributing to the Tajikistan economy is immigrant remittances [30], the export of gold, zinc ore, lead ore and raw cotton [31] and their growing reliance on China. The investment from China contributed to many projects under BRI, among them include the construction of a second power line initiated in 2015 to connect the capital, Dushanbe, with distant regions, the renovation of the road from Dushanbe to Khujand in the north as well the construction of tunnels along mountain routes Shakhriston and Khatlonskii [29].

\subsection{Turkmenistan}

In recent years, China has consistently pursued opportunities in the petroleum and natural gas sectors of Central Asia [32]. Turkmenistan, having the region's richest reserves of natural gas, has a special role in this strategy. The interests of the two countries have overlapped since Turkmenistan needs vast investments to develop new natural gas deposits, and China has surplus cash to invest. The share of China in the Turkmen trade volume surpassed 55 percent [33]. For Turkmenistan, China has become the largest trading partner. Moreover, the two countries are each other's largest cooperative partners in natural gas [34].

\subsection{Uzbekistan}

The country has experienced a total of 14.9 percent economic growth between 2017 and 2019 which among the factors causing such growth is the BRI [35]. Agriculture and manufacture contribute equally to the GDP. Since the introduction of BRI up to the end of 2019, total import and export have increased to about 43 percent and 20 percent respectively [36] [37]. China under the BRI has invested billions of dollars into the Uzbekistan economy [16].

\subsection{Summary of Projects Under BRI in Central Asia}

For this study on-going and executed projects under the BRI are categorized into the industry, road and railway, energy, mineral, petroleum extraction, finance and IT, agriculture, workshop, and training. Table 2.0 below provides the cost and category of all the products undertaken under the BRI.

Table2.0. Category of products undertaken under the BRI and their proposed cost [38].

\begin{tabular}{|l|l|l|}
\hline COUNTRY & CATEGORY & AMOUNT (US\$ MILLION) \\
\hline Kazakhstan & Agriculture & 1049.63 \\
\cline { 2 - 3 } & Workshop \& training & 12.93 \\
\cline { 2 - 3 } & Financial \& IT & 8100 \\
\cline { 2 - 3 } & Industry & 6485.5 \\
\cline { 2 - 3 } & Road and railway & 6475.3 \\
\cline { 2 - 3 } & Energy & 4651 \\
\cline { 2 - 3 } & Mineral and petroleum extraction & 17185.5 \\
\hline \multirow{5}{*}{ Kyrgyzstan } & Agriculture & 31.55 \\
\cline { 2 - 3 } & Workshop \& training & 46.44 \\
\cline { 2 - 3 } & Financial \& IT & - \\
\cline { 2 - 3 } & Industry & 150.8 \\
\cline { 2 - 3 } & Road and railway & 1327.26 \\
\cline { 2 - 3 } & Energy & 2505 \\
\hline
\end{tabular}




\begin{tabular}{|c|c|c|}
\hline & Mineral and petroleum extraction & 60 \\
\hline \multirow{7}{*}{ Tajikistan } & Agriculture & 65 \\
\hline & Workshop \& training & - \\
\hline & Financial \& IT & - \\
\hline & Industry & 679.8 \\
\hline & Road and railway & 235.9 \\
\hline & Energy & 4038 \\
\hline & Mineral and petroleum extraction & 200 \\
\hline \multirow{7}{*}{ Turkmenistan } & Agriculture & - \\
\hline & Workshop \& training & - \\
\hline & Financial \& IT & - \\
\hline & Industry & - \\
\hline & Road and railway & 1402.5 \\
\hline & Energy & 600 \\
\hline & Mineral and petroleum extraction & 13430 \\
\hline \multirow{7}{*}{ Uzbekistan } & Agriculture & 28.7 \\
\hline & Workshop \& training & - \\
\hline & Financial \& IT & - \\
\hline & Industry & 920.05 \\
\hline & Road and railway & 1000 \\
\hline & Energy & 205.3 \\
\hline & Mineral and petroleum extraction & 2209.3 \\
\hline
\end{tabular}

\section{BRI IN CENTRAL ASIA: OPPORTUNiTIES AND ChallengeS}

\subsection{Opportunities}

The BRI provides opportunities for Central Asia by serving as a gateway connecting China with West Asia and Europe, expanding trade, building infrastructure and attracting foreign investment [7].

Infrastructure development and intra-regional cooperation under the BRI have created an unprecedented environment in Central Asia, which raises expectations towards Japan and may open up new business opportunities. As Johannes F. Linn and Leo Zucker say "Despite the overwhelming evidence that infrastructure maintenance is critical, recent studies on infrastructure, connectivity and the BRI often neglect the O\&M dimension, and specifically the need to adequately maintain infrastructure assets," [39] there will be an increasing need for operating and maintaining infrastructure developed under the BRI.

Chinese private companies are based on the growing middle-class and distribution networks developed in Asia. They see the region as an area with an electronics, internet and real estate potential [40].

Central Asia once played an important role in the old Silk Road, but this region has not appeared on the global stage for several centuries. Since the collapse of the Soviet Union, Central Asian countries have faced tremendous political, economic, and social difficulties. The New Silk Road (BRI) may be the initiative that provides Central Asia with opportunities to actively engage with global trade once again [20].

\subsection{Challenges to BRI in Central Asia}

Delays involved in the crossing of borders, foreign direct investment (FDI), and cumbersome customs procedures and restrictions tend to affect the effectiveness of BRI. It takes up to 50 days to comply with all procedures to import goods in Central which is more as compared to the G7 countries which are 10 days. In terms of starting a foreign business, accessing industrial land, and arbitrating commercial disputes, Central Asian countries have more restrictive and burdensome FDI policies than high-income OECD countries [41].

Legal institutions along the BRI routes are still embracing international dispute resolution. It would take time for investors to build confidence in these domestic legal systems. There are also significant challenges created by the different legal systems involved in the cross-border BRI projects. Ms.Tursunova pointed out that the BRI creates significant risks for investors because many of the large projects' contracts are negotiated and executed separately on a country-by-country basis, 
meaning that investors sometimes have to fight in different fora with different countries at the same time [42].

Conditions for loans to Central Asian countries under which state the country should use Chinese technologies and hire Chinese workers don't contribute to the development of local industry and reduction of unemployment in the region. This high unemployment rate has to lead to many Kyrgyzstan and Tajikistan migrating to work in Russia. According to the World Bank, personal remittances in 2017 accounted for 32.9 percent of GDP in Kyrgyzstan and 31.3 percent in Tajikistan, meaning that the economies of both countries are supported by remittances from migrant workers as a result of the unemployment in these countries.

Central Asian governments are also reluctant to disclose information. Their lack of transparency on debt and on China's BRI activities, as well as the prevalence of corruption and low confidence in governments and officials, both of which are particularly pronounced in Central Asia, has sparked protests in the region. In 2016, there was a series of protest in Kazakhstan about a bill which would permit leasing land to foreigners. There was a concern about the Chinese move to take land from the locals which lead to the removal of Prime Minister Massimov from his post. Similarly, in 2019, there was a report of series of protests in Kyrgyzstan against the growing influence of China, urging the authorities to deport illegal Chinese migrants and to stop granting them citizenship, as well as to investigate how the country's financial borrowing to China is being used [43].

\section{CONCLUSION}

Central Asia is one of the vital regions for China. Since 2013, BRI has successfully been implemented in Central Asia, facilitating trade and developing infrastructure in the region. Through BRI, China will certainly remain the largest investor in Central Asia. China and Central Asia are bound together by geography, economy, and history. Although all countries have their specifics, there are certain similarities in the project in Central Asia.

The main focus of BRI in the region is to contribute infrastructural development with the aim to connect China to Europe through the region. Among all the projects done under BRI, the biggest projects under the BRI in terms of the total sums invested are projects under the category of mineral and petroleum extraction.

The only key challenge related to the implementation of BRI is the perception of some of the local residents about China benefiting more from the initiative than countries in the region. Therefore, there is a need for reforms in the implementation of BRI within the region for the locals in the region to have faith in China as a long-term economic partner.

Author Contributions: Diana Toktogulova is a master student of Fujian University of Technology; Dr. Weiqing Zhuang: Associate Professor \& Vice Dean of the School of Internet Economics and Business of Fujian University of Technology (China), and a postdoctoral fellow of the University of Central Florida (USA), received the Ph.D. in management science from Xiamen University, China, and has research interests focused on BDA in e-commerce, interorganizational information systems, machine learning, etc.

Funding: This work was supported by the Ministry of Education's Humanities and Social Sciences Research Project (No. 18YJAZH153), Fujian Natural Science Foundation (No. 2018J01648), Development Fund of Scientific Research from Fujian University of Technology (No. GY-S18109), all received from the Chinese government.

\section{REFERENCES}

[1] C. R. Service, "ChinA's ECONOMic Rise: History, Trends, Challenges, and Implications For the United States," 2506 2019. [OnLINE]. AVAILABlE: HTtPS:/FAS.ORG/SGP/CRS/ROW/RL33534.PDF. [ACCESSED 2602 2020].

[2] V. Kong, S. C. Cochrane, B. Meighan and M. WALSH, "The Belt and Road Initiative-SiX Years ON," $06 \quad 2019 . \quad$ [ONLINE]. AVAILABLE: HTTPS://WWW.MOODYSANALYTICS.COM//MEDIA/ARTICLE/2019/BELT-AND-ROAD-INITIATIVE.PDF. [ACCESSED 1602 2020].

[3] "China Power Project," International Center for Strategic \& Studies, [Online]. Available: HTTPS://CHINAPOWER.CSIS.ORG/CHINA-BELT-AND-ROAD-INITIATIVE/. [ACCESSED 26022020 ]. 
[4] J. Tian, "'One Belt And One RoAD': CONNECTing ChinA AND THE WORLD," McKinsey COMPANy, 06 2016. [ONLINE]. AVAILABLE: HTTPS://WWW.GLOBALINFRASTRUCTUREINITIATIVE.COM/ARTICLE/ONE-BELTAND-ONE-ROAD-CONNECTING-CHINA-AND-WORLD. [ACCESSED 1502 2020].

[5] H. Chin and W. He, "The Belt and Road Initiative: 65 Countries And Beyond," 05 2016. [OnLine]. AVAILABLE: HTTPS://WWW.FBICGROUP.COM/SITES/DEFAULT/FILES/B\%26R_INITIATIVE_65_COUNTRIES_AND_BEYOND.P DF. [ACCESSED 1302 2020].

[6] T. S. Council, "The Belt and Road Initiative," The People's Republic ofChina, [Online]. AVAILABLE: HTTP://ENGLISH.WWW.GOV.CN/BELTANDROAD/. [ACCESSED 1202 2020].

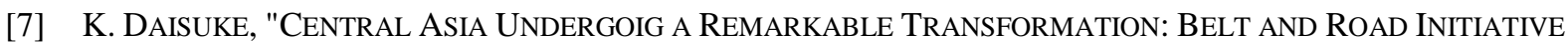
AND InTRA Regional COOPERATION," Mitsu \& Co. Global StraEgic InstituTe, ToKyo, 2019.

[8] OECD, "China's Belt and RoAd Initiative in the Global Trade, Investment and Finance LANDSCAPE," [ONLINE]. AVAILABLE: HTTPS://WWW.OECD.ORG/FINANCE/CHINAS-BELT-AND-ROADINITIATIVE-IN-THE-GLOBAL-TRADE-INVESTMENT-AND-FINANCE-LANDSCAPE.PDF. [ACCESSED 26022020 ].

[9] H. Chin and W. He, "The Belt and Road Initiative: 65 Countries And Beyond," 05 2016. [OnLine]. AVAILABLE:HTTPS://WWW.FBICGROUP.COM/SITES/DEFAULT/FILES/B\&R_INITIATIVE_65_COUNTRIES_AND_ BEYOND.PDF. [ACCESSED 0502 2020].

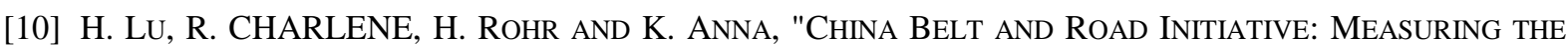
IMPACT OF IMPROVING TRANSPORTATION CONNECTIVITY ON TRADE IN THE REGION," RAND CORPORATION, ANTA MONICA, CALIFONIA, 2018.

[11] S. Bernhard , "CAN The New Silk Road Compete With The Maritime Silk RoAd? In The Maritime EXECUTIVEE," 2020.

[12] S. World, "List of COUntries By GDP (Nominal)," 1201 2020. [Online]. Available: HTTP://STATISTICSTIMES.COM/ECONOMY/COUNTRIES-BY-GDP.PHP. [ACCESSED 2806 2020].

[13] S. Bhutia, "Who Wins in ChinA’s GREAT CENTRAL ASIA SPENDing SPREe?" EuRASiANET, 02102019. [ONLINE]. AVAILABLE: HTTPS://EURASIANET.ORG/WHO-WINS-IN-CHINAS-GREAT-CENTRAL-ASIA-SPENDINGSPREE. [ACCESSED 0907 2020].

[14] C. TRADE, "CENTRAL ASIA: IS THE MÉNAGE À TROIS WITH CHINA AND RUSSIA SUSTAINABLE?," $18 \quad 04$ 2019. [ONLINE]. AVAILABLE: HTTPS://WwW.COFACE.COM/NEWSPUBLICATIONS/PUBLICATIONS/CENTRAL-ASIA-IS-THE-MENAGE-A-TROIS-WITH-CHINA-AND-RUSSIASUSTAINABLE. [ACCESSED 2806 2020].

[15] V. Julien, "TAMing the Bear While Riding the DRAgOn? CEnTRAL Asia Confronts Russian AND CHINESE ECONOMIC INFLUENCES," [ONLINE]. AVAILABLE: HTTPS://JOURNALS.OPENEDITION.ORG/REGULATION/13626?LANG=EN\#FTN14. [ACCESSED 1602 2020].

[16] V. Paramonov, "China's Economic Presence in Uzbekistan: Realities and Potentials," UZBEKISTAN INITIATIVE PAPERS, TASHKENT, 2014.

[17] P. VLADIMIR, "ChINA's ECONOMIC PRESENCE IN UZBEKISTAN: REALITIES AND POTENTIALS,"UZBEKISTANINITIATIVE, PP. 1-10, 2014.

[18] "Belt and Road Initiative," EuRopean BAnK of ReCONSTRUCTION AND DEVElopment.

[19] H. Wang, "China's Triple Wins: The NeW Silk RoAds," 2016. [Online]. Available: HTTPS://WWW.FORBES.COM/SITES/HELENWANG/2016/01/15/CHINAS-TRIPLE-WINS-THE-NEW-SILKROADS/\#197446D76F7F. [ACCESSED 2102 2020].

[20] M. Jochec AND J. J. KyZY, "ChInA's BRI InVESTMENTS, RisKS, AND OPPORTUNiTIES IN KAZAKHSTAN AND Kyrgyzstan," The George Washington University, Washington, D.C., 2018.

[21] Eurasianet, "TAJikistan, TURKMENiSTAN SubMit to ChinESE CAPTURE," 2016.

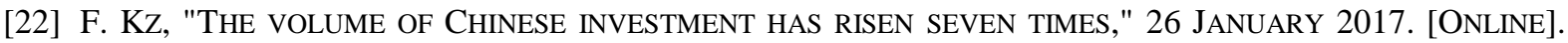
AVAILABLE: HTTPS://FORBES.KZ/NEWS/2017/01/26/NEWSID_133690.

[23] W. BANK, "ThE WORLD BANK IN KAZAKHSTAN," [ONLINE]. AVAILABlE: HTTPS://WWW.WORLDBANK.ORG/EN/COUNTRY/KAZAKHSTAN/OVERVIEW. [ACCESSED 1602 2020].

[24] R. Standish, "ChinA’s Path Forward Is Getting Bumpy," The Atlantic, Nur-Sultan, 2019.

[25] A. Gabuev, "Friends With Benefts? RuSSIAN-Chinese Relations AFer the UKraine CRISIS," CARNEGIE MOSCOW CENTER HTTPS://CARNEGIE.RU/2016/06/29/FRIENDS-WITH-BENEFITS-RUSSIANCHINESE-RELATIONS-AFTER-UKRAINE-CRISIS-PUB-63953, 2016.

[26] G. Shtraks, "SEARCh ChinA’s One Belt, One RoAd Initiative".

[27] A. TOleukhanova, "KaZAKhstan \& China: Fear, LoAThing AND Money," Eurasianet HTTP://WWW.EURASIANET.ORG/NODE/79336, 2016.

[28] K. Tinibai, "KaZakhstan and China: A Two-Way Street," Transitions Online, 2010. 
[29] A. Wolters, "Hegemonic or Multilateral? Chinese InVESTMENTS AND the BRI INITIATIVE IN TAJIKISTAN AND KYRGYZSTAN," (OSCE ACADEMY, BISHKEK, 2018.

[30] ECONOMist, "CEnTRAl Asia AND itS Russian DEPENDENCE," 097 2013. [OnLine]. AVAilable: HTTPS://WWW.ECONOMIST.COM/ASIA/2013/09/07/REMITTANCE-MAN. [ACCESSED 1802 2020].

[31] OEC, "TAJikistan," [ONLINE]. AvaILABLE: HTTPS://OEC.WORLD/EN/PROFILE/COUNTRY/TJK/. [ACCESSED 1802 2020].

[32] I. JumayeV, "Foreign Trade of Turkmenistan:," UCA COMMuniCATIONS DePARTMEnT, 2012.

[33] Directorate General For Trade European COMMisSion, "European Union, Trade IN GOODS WITH TURKMENISTAN," 2018.

[34] C. DAILY, "CHINA-TURKMENISTAN TIES BECOMING HTTP://WWW.CHINADAILY.COM.CN/CHINA/2013XIVISITCENTERASIA/2013-09/02/CONTENT_16936006.HTM, 2018.

[35] W. BANK, "COUNTRy ECONOMIC Update SumMER -UzBeKistan," [Online]. Available: HTTP://DOCUMENTS.WORLDBANK.ORG/CURATED/EN/866501562572675697/PDF/UZBEKISTAN-TOWARD-ANEW-ECONOMY-COUNTRY-ECONOMIC-UPDATE.PDF. [ACCESSED 2302 2020].

[36] "The State Committe of the Republic of Uzbekistan on Statistics," [Online]. Available: HTTPS://STAT.UZ/EN/2-UNCATEGORISED/6694-MACROECONOMIC-INDICATORS2. [ACCESSED 2302 2020].

[37] M. Shahbandeh, "COTTON PRODUCtion By COUNTRy WORLDWIDE, 2019," 24092019. [ONLINE]. AVAILABLE: HTTPS://WWW.STATISTA.COM/STATISTICS/263055/COTTON-PRODUCTION-WORLDWIDE-BY-TOPCOUNTRIES/. [ACCESSED 2302 2020].

[38] F. Aminjonov, A. Abylkasymova, A. Aimee, B. Eshchanov, B. Eshchanov, D. Moldokanov, I.

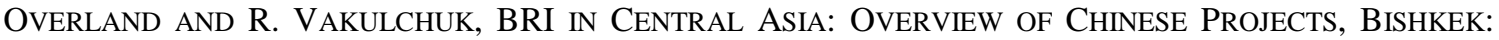
NORWEGIAN INSTITUTE OF INTERNATIONAL AFFAIRS, 2019.

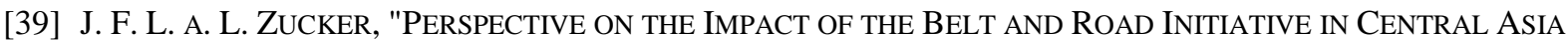
AND THE SOUTH CAUCASUS," "INSIDE-OUT", 2019.

[40] B. McKenzie., "Belt \& RoAd: Opportunity \& Risk," Silk RoAd Associates, Singapore, 2017.

[41] M. Ruta, "Three Opportunities AND Three Risks of The Belt AND RoAD Initiative," World BANK BLOGS, 2018.

[42] T. Chen, "ISDS As a Means of AdDressing Challenges fOR the BRI in Central Asia," KLuwer ARBITRATION BLOG, $05 \quad 07$ 2019. [ONLINE]. HTTP://ARBITRATIONBLOG.KLUWERARBITRATION.COM/2019/07/05/ISDS-AS-A-MEANS-OF-ADDRESSINGCHALLENGES-FOR-THE-BRI-IN-CENTRAL-ASIA/. [ACCESSED 3101 2020].

[43] D. Kliman, R. Doshi, K. LeE and C. Zack , "Grading China's Belt and Road," Center For A New AMERICAN SECURITY, WASHINGTON, DC, 2019.

[44] D. Kitade, "Central Asia Undergoing a Remarkable Transformation: Belt and Road Initiative

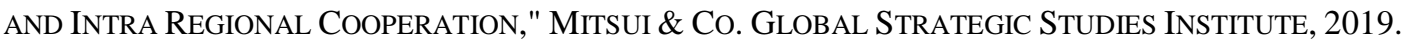

[45] T. W. BANK, "GDP PER CAPITAL (CONSTANT 2010 US\$)," [ONLINE]. AVAILABLE: HTTPS://DATA.WORLDBANK.ORG/INDICATOR/NY.GDP.MKTP.CD?LOCATIONS=KG-KZ-UZ-TJ-TM. [ACCESSED 1602 2020].

[46] Z. Yuri, "KaZakhstan COMES ON Strong," TIME, 2709 2006. [Online]. Available: HTTP://CONTENT.TIME.COM/TIME/WORLD/ARTICLE/0,8599,1539999,00.HTML. [ACCESSED 1602 2020].

[47] T. Watkins, "The Political and Economic History of Kazakhstan," ApPlet-Magic, [OnLine]. AVAILABLE: HTTP://WWW.APPLET-MAGIC.COM/KAZAKHSTAN.HTM. [ACCESSED 1602 2020].

[48] [ONLINE]. AVAILABLE: HTTP://WWW.STAT.KG/RU/STATISTICS/NASELENIE/. [ACCESSED 1602 2020].

[49] WORLDOMETER, "TAJIKISTAN POPULATION," [ONLINE]. AVAILABLE: HTTPS://WWW.WORLDOMETERS.INFO/WORLD-POPULATION/TAJIKISTAN-POPULATION/. [ACCESSED 1802 2020].

[50] CIA, "THE WORLD $\quad$ FACTBOOK," [ONLINE]. HTTPS://WWW.CIA.GOV/LIBRARY/PUBLICATIONS/THE-WORLD-FACTBOOK/GEOS/TX.HTML. [ACCESSED 1902 2020].

[51] W. BANK, "THE WORLD BANK IN TURKMENISTAN," [ONLINE]. AVAILABLE: HTTPS://WWW.WORLDBANK.ORG/EN/COUNTRY/TURKMENISTAN/OVERVIEW. [ACCESSED 1902 2020].

[52] C. FACTBOOK, "UZBEKISTAN," [ONLINE]. AVAILABLE: HTTPS://WWW.CIA.GOV/LIBRARY/PUBLICATIONS/THE-WORLD-FACTBOOK/GEOS/UZ.HTML. [ACCESSED 2302 2020].

[53] Gazeta, "Population InCREAsed of 650,300 IN ONE YEAR," 202001 27. [OnLine]. Available: HTTPS://WWW.GAZETA.UZ/RU/2020/01/27/POPULATION/. [ACCESSED 2302 2020]. 
[54] H. Xiaoying, "China-KaZakhstan cooperation Continues," BeiJing, 2008.

[55] M. O. E. O. T. K. RePUblic, "POSTUPLENIIA PRIAMYKH INOSTRANNYKH INVESTITSII ZA 2016 G., HTTP://MINECONOM.GOV.KG/DOCS/ORM/_2016_.PDF.," BISHKEK, 2016.

[56] T. ECONOMics, "TAJikistan Balance OF TRADE," [Online]. Available: HTTPS://TRADINGECONOMICS.COM/TAJIKISTAN/BALANCE-OF-TRADE. [ACCESSED 1802 2020].

[57] N. $\quad$ B. $\quad$ O. $\quad$ S. $\quad$ O. $\quad$ CHINA, "ANNUAL DATA," HTTP://WWW.STATS.GOV.CN/ENGLISH/STATISTICALDATA/ANNUALDATA/, 2018.

[58] C. Fellows, "HTTP://WwW.RUSSEDINA.RU".

[59] M. O. F. A. O. T. P. R. O. CHINA, HTTPS://WWW.MFA.GOV.CN/WEB/, 2018.

[60] U. Hashimova, "Why Central Asia Is Betting on China's Belt and Road," The Diplomat, 2018.

[61] Swiss Re Institute, "China's Belt \& RoAd Initiative: the impact on COMMERCial insurance IN PARTICIPATING REGIONS," 2017.

[62] C. R. Guluzian, "Making Inroads: China’s New Silk Road initiative," Cato Journal 37, no. 1, 2017.

[63] H. Alf, "Markt unter Druck. Der Dordoi-Basar in Kirgistan unter Dem Einfuss von EURASISCHER WIRTSCHAFSUNION UND WIRTSCHAFSKRISE," ZENTRALASIENANALYSEN 105 (2016): 2-6, 2016.

[64] Parag Khanna, "The New Silk Road is made of IRON AND STREtches From Scotland to SINGAPORE," QUARTZ, 2012.

[65] P. Duarte, "China In the Heartland: The Challenges and Opportunities of OBOR For Central ASIA," UNIVERSIDADE AUTÓNOMA DE LISBOA, LISBON, 2018.

[66] M. J. A. J. J. KYZY, "CHINA'S BRI INVESTMENTS, RISKS, AND OPPORTUNITIES IN KAZAKHSTAN AND Kyrgyzstan," The George Washington University, Central Asia Program, 2018.

\section{AUTHORS' BIOGRAPHIES}

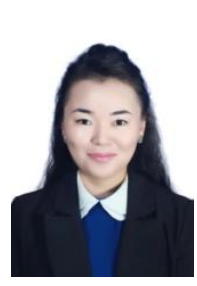

Diana Toktogulova, School of Management, Fujian University of Technology, Fuzhou, Fujian, China 350118

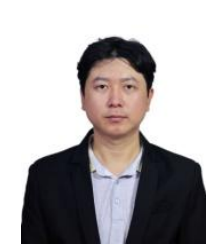

Weiqing Zhuang, School of Internet Economics and Business, Fujian University of Technology, Fuzhou 350108, China\&Research Center for "One Belt and One Road" Economic and Policy, Fujian University of Technology, Fuzhou 350108, China

Citation: Diana Toktogulova, Weiqing Zhuang. "A Critical Analysis of the Belt and Road Initiative in Central Asia" International Journal of Managerial Studies and Research (IJMSR), vol 8, no. 8, 2020, pp. 4251. doi: https:// doi.org/10.20431/2349-0349.0808005.

Copyright: (1) 2020 Authors. This is an open-access article distributed under the terms of the Creative Commons Attribution License, which permits unrestricted use, distribution, and reproduction in any medium, provided the original author and source are credited. 